\title{
HCAR1 Gene
}

National Cancer Institute

\section{Source}

National Cancer Institute. HCAR1 Gene. NCI Thesaurus. Code C150255.

This gene plays a role in lactate-dependent signaling. 